\title{
O Dever de desguetização da População Negra. Estudo Cruzado entre Campinas, Brasil, e Cidade do Cabo, África do Sul
}

\author{
The Duty of Deghettoization of Black Population Based Upon Un / \\ Habitat III's New Urban Agenda: a Crosss study Between \\ Campinas, Brazil and Cape Town, South Africa ${ }^{1}$
}

Josué Mastrodi ${ }^{2}$

Waleska Miguel Batista ${ }^{3}$

\section{RESUMO}

A Agenda da ONU/Habitat III recomenda que as cidades sejam includentes, buscando, por meio de planejamento urbano a eliminação de todos os tipos de desigualdades sociais, incluído aqui, de forma explícita, o racismo. Campinas (Brasil) e Cidade do Cabo (África do Sul) possuem similaridades no que respeita a segregação socioespacial segundo critérios étnicos, já que ambos os países parecem possuir o racismo como um fundamento de suas relações sociais, especificamente, o ODS número 11 da Agenda 2030, de tornar as cidades racialmente includentes. Analise-se através do estudo cruzado entre as duas cidades mencionadas.

\section{PALAVRAS-CHAVE:}

Racismo. Planejamento Urbano. ONU/Habitat III. Segregação. Sustentabilidade

\begin{abstract}
The New Urban Agenda adopted by the UN/Habitat III Conference recommends cities to be inclusive, seeking to eliminate social inequalities, including racism, through urban planning. Campinas (Brazil) and Cape Town (South Africa) have similarities regarding racism as ground for their social structures, there is socio-spatial segregation according to ethnic criteria, specifically Sustainable Development Goal number 11 of the UN/Habitat Agenda 2030, to make cities racially inclusive. This research will be undertaken in the form of a cross study between cities.
\end{abstract}

\section{KEYWORDS:}

Racism; Urban Planning. UN/HABITAT III. Segregation. Unsustainability.

\footnotetext{
${ }^{1}$ This work was carried out with support from the Coordenação de Aperfeiçoamento de Pessoal de Nível SuperiorBrasil (CAPES)- financing code 001.

${ }^{2}$ Doutor em Teoria Geral e Filosofia do Direito pela Universidade de São Paulo e Professor dos Programas de Pós-Graduação Stricto Sensu em Sustentabilidade e em Direito da Pontifícia Universidade Católica de Campinas.

3 Doutoranda em Direito Político e Econômico pela Universidade Presbiteriana Mackenzie/SP, Mestra em Sustentabilidade e Graduada em Direito, pela Pontifícia Universidade Católica de Campinas
} 


\section{INTRODUÇÃO}

In the Habitat III Conference in Quito, ${ }^{4}$ it was said, because of a strong bias against the poor, migrants and ethnic groups, these are unfairly singled out as the culprits for the existence of urban violence and the formation of slums and occupations. Inspired by the Sustainable Development Goal number 11 of the United Nations Agenda 2030, there were proposals for the UN Member States to implement policies so that cities become inclusive, resilient and sustainable. In this paper, we treat the conditions of transformation of cities in the aspect of social sustainability, specifically in regards to the integration of black people and their deghettoization.

Both the UN / Habitat III's Urban Agenda as the domestic laws of Brazil and South Africa have devices which affirm that the State should be equal, averse to prejudice and discrimination, since both countries claim to be democratic. From a crossover study --also known as transversal-- between Campinas, Brazil, and Cape Town, South Africa, we identify similarities in the formation of their urbanization, which brings to light that the black population was not as included as the white population.

Brazil experienced a period of about 300 years of slavery regime, and South Africa had the same for 350 years, a situation that, in both countries, laid the structuring of a social reality that determined, institutionally, that an ethnic group was inferior and the other, superior to the former. In both countries, the white men ended up establishing themselves as the top group, while the other groups were subordinated, the Brazilian and South African societies segregated into two groups: dominant and dominated, respectively, white and black (non-white).

In South Africa, the abolition of slavery took place in 1834. In 1949, the National Party came to power, which went on to establish racist standards, which separated the population in Indian, coloured, African and white. Angela Davis (2017: 24) states that both the apartheid as another irrationality of the twentieth century, the arms race, only lasted for so long, and had the

\footnotetext{
${ }^{4}$ UN Conference on Housing and Sustainable Urban Development, which took place from 17 to 20 October 2006, in Quito, Ecuador, reaffirmed the political commitment to the quest for sustainable urban development (NEW URBAN AGENDA, 2016).
} 
formation of discriminatory behavior so profound, because the dominant social groups benefited from it. ${ }^{5}$

According to Angela Davis (2017: 92) in 1985, South Africa had "4.3 million white people, 18.6 million black people and 3.1 million people of mixed or Asian origin." Black people were not citizens because they had no right to vote, couldn't move freely around and through the city, having been relegated to unproductive and remote areas. The non-white movement in the areas defined as "white areas" was permitted only to those who had an authorization card, that is, a public document which stated that that non-white was there to work, and could only be there during the hours of their service (MBEMBE, 2014: 12-13).

The fall of the apartheid system occurred in 1990, though racial segregation remains, although there is no legislation that lends legal basis to it. (SILVA, 2013: 46-47). ${ }^{6}$

With the formal end of the segregationist regimes, both South Africa and Brazil present themselves to the international community as multiethnic and multicultural countries, but still reproduce discrimination and prejudice against black men and women, so that the apartheid, that is, the social division between two racial groups, still persists in the twenty-first century. Even today, the stigmatization and exclusion of blacks impede social mobility and consolidate racism in all social fields.

Brazil and South Africa maintain concentrated black population, massively, in the suburbs, ghettos and slums, since it was not included in the legal territory of the city, ${ }^{7}$ not being regarded as holder of the citizenship granted to whites. Similarly, Wacquant (2008: 53-60) pointed out that the ghetto formed an opposing city but still connected to white society, which had extensive infrastructure, goods and services. It was a city within the city.

\footnotetext{
${ }^{5}$ The author came to this conclusion when witnessing the American industries placed in South African cities under the covenant made by the US president, Ronald Reagan and the President of South Africa, P. W. Botha (19841989). However, seeing as the southern United States was the "American Johannesburg" black and political movements protested against the alliance held. The strength of these groups was grand because some American companies were withdrawn from South Africa, and others were vetoed, the point of the struggle against "constructive engagement of the Reagan administration be challenged" (Davis, 2017: 93).

${ }^{6}$ According to analysis of the Cape Town census data, there is an immense economic and social gap between whites and non-whites, which allows us to affirm the inferiority of non-whites (STATS SA, 2012).

${ }^{7}$ Maricato (2000: 122-123) said that for illegal cities, it represents a group that is marginalized because of economic and ideological forces that perpetuate the pre-republican conditions, i.e. segregationist. As for the legal cities, these are the ones reached by public goods, services and equipment (sanitation, health, education etc.).
} 
This shows the strength of the racial theories, which formed a completely oppressive system even as the structural violence is absent (that established racism and justified it with legal standards). However, due to the ideology of equality or racial democracy, segregation structure and the repeated practice of racism are systematically denied.

Henri Lefebvre (2001: 98-99) said, not necessarily about racial inequality, but about segregation in cities, that in a democratic country segregation is not publicly decreed, a humanistic approach is adopted instead, nothing but simple talk that is just talk. This only serves as means of not recognizing the inequality.

Thus, for the development of this study we used qualified periodicals and books on citizenship, right to the city, racism and racial inequality as well as the cross study between data on population, housing, education and income collected on the official sites of the cities of Campinas and Cape Town.

First, we present the reproduction of racism in Brazil, and its social and legal aspects. Next, we reduce the study to the analysis of data from the city of Campinas, to see if there is need for a deghettoization policy. ${ }^{8}$ Then we aim for the formation of racism in South Africa since Dutch and English invasions, and how that plays into the twenty-first century, to the specific study of Cape Town. Finally, we see if our hypothesis that both Campinas and Cape Town are racist, turning it into a duty to implement a deghettoization policy that confronts racial inequality in the urban space.

\footnotetext{
${ }^{8} \mathrm{We}$ use the term deghettoization from neology "ghetto" in order to clarify that there is on the black population, at least in two cities studied, the incidence of perverting stigma, whereby blacks cannot mix with white, so those don't- defraud worthy values that they claim to have, so that blacks suffer the historic confinement, spatial and institutional segregation (Wacquant, 2004: 157). If there ghettos, they must be undone since it prevents the search for equality with inclusive cities. Worth mentioning that the expression ghetto was coined in the Chicago School, which pointed out that the ghettos were formed by blacks, who were kept subordinated specifically because of the racist Jim Crow laws (Wacquant, 2008).
} 


\section{BRAZIL: THE REPRODUCTION OF RACISM}

The nineteenth-century Brazil already had characteristics of being multiracial and pluralistic and at the same time, it showed a complex system of racial classification, where "skin color, hair texture and facial features, and other visible physical characteristics, were the determinants of racial category in which a person would be inserted "(SKIDMORE, 2012: 81).

The Brazilian society had established, through the dominant group composed of white people, that their phenotype represented superiority, having applied the "understatement of the early races." While blacks were considered the "least developed", regarded as uncivilized, which led some groups of scientists to determine that Brazil was an inferior nation, because part of its population was black (SKIDMORE, 2012: 110-111). Milton Santos said that in Brazil there is a line

like a visible mark that often has its focus on appearance as the first condition of objectivity and judgment, creating a demarcation line, which identifies and separates, despite the claims of individuality and citizenship of the other (SANTOS, 2002: 160)..$^{10}$

The racist system fostered the development of segregated cities, since the spaces were and still are- expanded and modified according to the interests of the dominant group, so that the dominated have no guarantees.

Each city developed variously, but was still structured from the perspective of differences culturally constructed about the racial or ethnic diversity, on account of the mixing theories. $^{11}$

Florestan Fernandes asserted that, between 1920 and 1930, the black population couldn't get jobs, even those considered "inferior" or informal, as a shoe shiner and newspaper

\footnotetext{
${ }^{9}$ The white superiority was alleged by Joseph Gobineau (1816-1882) who claimed that the Aryan race was the evolved descendant of the Nordic people. He mixed evolutionary theory of Darwin with a monogenist explanation, stating that mestizo nations were inferior because the mixture with uncivilized groups (non-white) created a degenerate race (Schwarcz, 1993: 83-84).

10 The author asserts that the classification of people into races (actually ethnic groups) was a way to keep track of the white group, causing black people to be inferiorized.

${ }^{11}$ Scientists had spread the idea that blacks belonged to an inferior race, so that they prevented progress in society. The solution for the "development" was miscegenation, because they believed there would come a time when all people would be white, providing the elevation of the black (FERNANDES, 2008: 296-297).
} 
delivery man. That left them only domestic services (FERNANDES, 2008: 33). This spurred some neighborhoods compounded mainly by black women and black men; because the living cost was lower, whereas these areas were known as substandard neighborhoods because its residents could not get jobs. These spaces became known as urban quilombos, in the words of Raquel Rolnik (1989: 7).

In 1940, Curitiba was affected by changes in the industrial and productive activities, so that the division of society into class, despite being economically more complex, allowed for greater possibilities of adjustment of the groups, to the extent that social mobility of blacks, mulattos, Italians, Germans, Poles and others "are determined by unique structural and functional requirements of a capitalist society" (IANNI 1972: 77).

The city of Curitiba, according to the National Census Service, pointed out that in 19401950, blacks were a minority and were in the worst social conditions. The data show that occupancy rates in the labor market, literacy and housing of blacks were worse compared to whites (IANNI 1972: 86-96).

The study in loco held in Florianopolis found that blacks were not accepted in middle or high-class neighborhoods that were white-dominated. The author even justifies that the higher the social class, the higher the rejection of blacks. However, if you have whites in the same social class of those blacks that were rejected, those have the possibility of being rejected as well. In poor neighborhoods, there are locations where the black and white get along, but in others they feel the hostility and contempt that comes from their white neighbor (IANNI 1972: 102-103).

The territorial division between the working class mainly composed of white people (proletariat) and lumpem proletariat (marginal population) formed mainly of black people made the black population group to be stigmatized as well as criminalized because it was also characterized as a group of hooligans, vandals and rapists of morality. ${ }^{12}$

In this sense, Brazil was structured according to an apartheid system, since racial segregation valued the white person and characterized a black person as "primitive" or

\footnotetext{
${ }^{12}$ The only moral recognized was from the dominant white group, which proclaimed the need for whitening with miscegenation, so that one could civilize the Brazilian state. "White was seen as better, which led naturally to an ideal of whitening, visible both in the most elite texts and folklore" (SKIDMORE, 2012: 87).
} 
"degenerate". Racial segregation has become an important component of socio-spatial division of the territory of the city; segregation is reproduced and perpetuated to the present day.

The white population remained in control of all the positions that promote public decisions, which remains an almost exclusive access to state services, while non-white people ${ }^{13}$ live relegated to poor localities, without the presence of the state and surrounded by poverty. Moreover, even the few blacks who can rise socially suffer discrimination and prejudice on the grounds of their ethnicity. ${ }^{14}$

On this track, it is understood that racism was structured as a system that promoted inequalities, so ingrained in society that its reproduction prevents the effectiveness of anti-racist or anti-apartheid regulations. ${ }^{15}$

The UN Special Rapporteur Izsák (2016: 17) pointed out in her report that the inequality of minorities allowed Brazil to develop methods to reverse the vulnerability of the black population, but in key areas such as education, employment, healthcare and housing, AfricanBrazilians remained at the bottom of the socioeconomic scale.

The Special Rapporteur showed that although Brazil had developed social policies on housing and family allowance to guarantee the welfare and health of the most vulnerable, the inequality in detriment of the black population remained large. The black population mostly resides on the outskirts of cities, in slums or housing complexes, entering the spaces dominated by the white population, like elitist neighborhoods, shopping centers and clubs, just as servants.

Standardization of this inequality causes that any modification of this structure is considered a violation of public order, so that whites remain in developed and structured environments, while black men and black women are in unstructured, dirty and inadequate spaces.

\footnotetext{
${ }^{13}$ All data of the census in South Africa continue to make the approach to the classification of people in white, Indian, colored and Africans.

${ }^{14}$ This point discerns South Africa from Brazil, because here people suffer segregation by skin color, while in South Africa it occurs by ethnic criteria (Guimarães, 2014).

${ }^{15}$ That is, even if there are many antisegregationist standards, social and political strategies continue to walk towards segregation (Lefebvre, 2001: 98).
} 
This meant that normalize the conditions of inequality, maintaining the inferiority and subordination of blacks, who have not benefited from an egalitarian society. From the moment that the behavior and idea that there is a specific place for blacks are reproduced, it becomes nature, to the point that "if we repeat something several times, it becomes normal. If we see something often it becomes normal. "16

When it comes to the right to the city, this was not secured to the black population. Incidentally, we have the hypothesis that the city was never planned with racial equality in mind. The black mobility is restricted by ethnic barriers, the same barriers that keeps blacks confined to neighborhoods with less public facilities and services, which affront both the antiapartheid standards as the principles of democratic equality, or even the UN / Habitat III Agenda.

In the twentieth century, there was the President Getúlio Vargas coup, and later, after a few years, the return of "democracy"; in 1964 the military took power, ushering in the military dictatorship.

With the end of the military dictatorship and the transition to a democratic country, the Constituent Assembly passed a new Constitution based on human and fundamental rights, and asserted the equality and freedom of all people.

\subsection{Brazil after the 1988 Constitution}

In Brazil, with the end of military dictatorship and redemocratization, the Constitution of 1988 was enacted, aiming to reach the community and guarantee the individual and social fundamental rights, clearly ordaining against racial inequality, so that racism, once seen as mere

\footnotetext{
${ }^{16}$ Chimamanda Ngozi Adiche (2012: 47-54) reinforced this idea as she recalled in a TED talk in 2012 that a boy of her class, while she was in high school, was placed as class monitor because he was a boy, though, in that moment, she had been first placed with the highest score of her entire class. And this was the requirement to be monitor. However, it was told that obviously only a boy could have such power. Thus, the author couldn't be the monitor because she was a girl, even if she had the highest marks. Available in: https://www.ted.com/talks/chimamanda ngozi adichie_we should_all be feminists?language=pt-br. Accessed: October 4, 2018.
} 
misdemeanor came to be defined as an inalienable and non-bailable crime, as described in Article 5, section XLII, as it was contrary to the fundamental rights list.

Were also signed and ratified by Brazil international conventions for the protection of individuals, regardless of ethnicity, belief and sexuality, such as the International Convention on the Elimination of All Forms of Racial Discrimination, 1965, promulgated by Decree $65.810 / 69$, with the requirement that the State party adopted measures to combat racism.

Other international human rights treaties have been internalized by Brazil, after the President's signature and publication of the Decree of the Executive Branch mentioned, including those relating to ethnic equality issues, such as the International Covenant on Economic, Social and Cultural Rights, January 24, 1992; the American Convention on Human Rights on September 25, 1992; the Optional Protocol to the Convention on the Elimination of All Forms of Discrimination against Women, on 28 June 2002 (VEDOVATO; BARRETO, 2015: 39-40).

This way, we could imagine that Brazil would act as a fully democratic country, without discrimination by racial criteria, because it illustrates an appearance of multicultural and multiracial democracy, anxious to carry the guarantee of linguistic and cultural diversity of its citizens (GUIMARÃES, 2006: 272 -273).

Starting from this ideological basis and as a result of the struggles of the Black Movement, which only was restructured with the end of military dictatorship (DOMINGUES, 2007: 111), our Federal Constitution, Title II, Article 5, section XLII, in the list of fundamental rights, prescribed only that the practice of racism sets up a non-bailable and imprescriptible crime, subject to imprisonment.

The infra-constitutional law, Law n. 7716/1989, as well as the Federal Constitution did not recognize racism as a national problem, and so did not induce any significant change in society, as the black population was not seen with singularity, that is, it was not recognized as a rights holder group, like the other ethnic or social groups (RODRIGUES, 2012: 82). ${ }^{17}$

\footnotetext{
${ }^{17}$ Blacks, even though they constitute the majority of the population, have extremely limited participation when they have any, employers in the position or in intellectual work, because these are socially established occupations for white people (FERNANDES, 2008: 69).
} 
But, to supposedly ensure racial equality, despite the constitutional prescription against racism, the Secretariat for the Promotion of Racial Equality was created by Law n. 10,678/2003, ${ }^{18}$ who had ministerial status, with a National Council for the Promotion of Racial Equality and later Law No. 12,288 / 2010 (Statute of Racial Equality) was also published, which became the true legal framework on all racial issues in Brazil.

Still, to ensure that there was social inclusion from a sustainable urban policy ${ }^{19}$ the City Statute was established by Law no. 10,257/2001, which provides that Brazilian cities are obligated to be sustainable, promoting social, economic and environmental location. This law does not prescribe the possibility of inclusion of blacks, despite dealing on urban policy. This is evidence that the extra-economical social rights, such as racism, didn't even come into discussion on a combat policy against urban segregation.

Article 2 of Law n. 10.257/2001 prescribes on the development goals of urban property social functions, guaranteeing the right to a sustainable city and planning for the spatial distribution of the population in the city, without displaying the recognition of the subordination aimed at blacks. ${ }^{20}$

To direct the construction of urban policy, the Federal Constitution dictates that the council shall have power to legislate with respect to sustainable urban planning, as long as the Master Plan is implemented.

In order to guarantee the state's performance and the citizens' activities in the "achievement of the sustainable development of cities", the Master Plan is indispensable,

\footnotetext{
${ }^{18}$ In 2016, after the political coup in the executive branch, SEPPIR was merged with the Secretary of Human Rights, Women's Secretariat and the Secretariat of Youth, being linked to the Ministry of Justice and Citizenship, which itself mitigated the power of performance and development to combat racism, so that the black population had their vulnerability expanded again.

${ }^{19}$ Brazil was already in a process of sprawling urbanization, segregated and exclusionary. Since 1960 there was funding for affordable housing in outlying areas of the centers and with low income. On June 18, 2001 the statute was approved by the Senate unanimously and was sanctioned by the President of the Republic Fernando Henrique Cardoso on 10 July 2001. Nevertheless, there were vetoes in the following areas.

${ }^{20}$ Art. 2 The urban policy aims to order the full development of the social functions of the city and of urban property subject to the following general guidelines:

I - guarantee of the right to sustainable cities, understood as the right to urban land, housing, environmental sanitation, urban infrastructure, transportation and public services, work and leisure, for present and future generations

IV - planning development of cities, the spatial distribution of population and economic activities of the municipality and the territory under its area of influence, in order to avoid and correct the distortions of urban growth and its negative effects on the environment;
} 
because it deals with the peculiarities that exist in each city to meet the demands of interest of the community (REIS; VENÂNCIO, 2016: 230-231). As the Master Plan has the purpose of establishing urban planning with objectives, goals and guidelines that benefits all inhabitants, it must be mandatory (AGUIAR, 1996: 35-37). ${ }^{21}$

Despite the ordinance of collective participation, the Master Plan is part of the discretion of the Public Administration, for social and economic barriers hinder the hearing the anguish of the people who (do not) occupy the city (REIS; VENÂNCIO, 2016: 231). Nevertheless, from the moment the search for the interest of all people is inexistent, urban planning ends up being a player of ideologies that deal with territory transformation in order to reach the "development" and "modernity" (SANTOS 1993: 110), but not social inclusion.

These devices are restricted to formal aspect, not even being applied in conjunction with international human rights standards so that housing problems, immobility, security and access to public facilities are not resolved (SANTOS, 1993: 111)

Despite all this legal apparatus, we limit the study of the endurance of apartheid of blacks in Brazil from the study of the city of Campinas, in the state of São Paulo.

\subsubsection{Campinas: Evidence of racist structures}

The city of Campinas was the last city in the world to accept the abolition of slavery, so that it remained entrenched in social behavior the inferiority of black people, to the point that the slave regime is still valued (CAMPINAS, 2018).

\footnotetext{
${ }^{21}$ Meirelles (2008: 549-550) states that the Plan is "the complex of legal regulations and technical guidelines for the overall and steady development of the municipality, from the physical, social, economic and administrative aspect", so that it reaches the interest of collectivity. This author also stated that the Master Plan should plan the city, in order that it offers urban security, both from natural disasters as the physical and patrimonial violence; and also urban functionality, requiring the city to be "human and functional, able to satisfy four of its primary social functions: housing, work, recreation and circulation" (Meirelles, 2008: 560-561). The City Statute establishes in its Article 4, section III, point a, that the Master Plan is one of the instruments of urban policy, and the Federal Constitution, Article 182, paragraph 1, It states that the cities that have more than twenty thousand $(20,000)$ inhabitants should have the plan. The City Statute broadens the list of municipalities that need to elaborate master plan including, for example, all belonging to metropolitan areas and all those who decide to receive transfers of federal funds.
} 
Despite the normative acts that prescribe the social inclusion of blacks in the same measure as that provided to white, with access to equipment, public goods and services, education, health and housing, IBGE data from the Sustainable Cities Program and IPEA show that the black population remains marginalized and inferiorized.

Data from the IBGE Cities (2018) report that the estimated population of Campinas in 2018 is $1,194,094$ people, with a population density of 1359.60 inhabitants per square kilometer.

The Atlas of development in 2013 illustrated with the 2010 census data that the black population of the city of Campinas live the most vulnerable experiences compared to the white population.

The Municipal Human Development Index (MHDI) of the black population of Campinas, in 2010, was 0,741, and white population figured 0,836. Both results are high, but there is a difference in absolute numbers of 0,095. The components considered for the results presented ranged from mortality, income, education level and housing.

The black population fertility percentage is higher than that of the white population, $2.2 \%$ and $1.4 \%$, respectively. However, life expectancy at birth is lower for blacks, $76.2 \%$, against $77.1 \%$ for whites.

In Campinas, the monthly per capita income in 2010 was $\mathrm{R} \$ 735.00$ for blacks and $\mathrm{R} \$$ 1696.71 for whites. In 2016, inequality on the income received by the two groups persisted up to the point that blacks continued to receive less than whites, despite having been six years since the publication of the Statute of Racial Equality. ${ }^{22}$

The data show that, among young people from Campinas from 18 to 20 years with a high school education, blacks represent $38.61 \%$ while $61.26 \%$ are white. This difference reflects the fact that blacks are minorities in public and private universities, since the number of young black people who have completed high school was lower than that of whites. It is

\footnotetext{
${ }^{22}$ IBGE data showed that in 2016, the black population was estimated at $55.4 \%$ (114.1 million) and the white population at $43.8 \%$ (90.2 million). Despite being majority, the data at the national level reveals that blacks receive lower wages and are in the condition of unemployment in greater numbers when compared to whites (IBGE, 2016).
} 
found that $6.7 \%$ of black people had completed higher education, while the percentage was $27.3 \%$ for white people.

As for housing, it should be taken into account the existence of piped water, electricity, garbage collection, sanitation, afforestation, urbanization and public roads.

The 2010 IBGE data show that blacks have less housing with running water than white people, respectively, $96.48 \%$ and $97.87 \%$. The existence of access to electricity and garbage collection has a tiny difference, being respectively $99.96 \%$ and $99.68 \%$ for blacks and $99.99 \%$ and $99.86 \%$ for whites.

As for sanitation, afforestation and urbanization of public roads, there was no appointment by ethnic and racial criteria.

The Sustainable Cities Program (SCP) is a program designed to provide indicators to assess whether the city of Campinas has implemented policies that enable the achievement of the goal 11 of Agenda 2030 to promote inclusive, resilient and safe cities. However, there are no signs that the government has interest in the development as set out in the SCP. Just as an example, we refer to three of the indicators that seemed more directly related to the object of this research. In none of them there is a contribution to the quantification of the racial problem in Brazil:

I. Planning and urban design, there was the expectation to analyze the housing deficit and the population living in substandard clusters. However, the analysis of the first item remains impaired, because there has not been the preparation of any report or data that approaches it in the program. The second found that the population of Campinas living in substandard homes is increasing, perhaps as a result of gentrification processes, combined with the economic crisis. ${ }^{23}$

II. Equity, Social Justice and Culture of Peace, in the axes for affirmative actions to reduce inequality, white and black population homicide and Human Development Index. The analysis of the first axis remains hampered because there is no registration within the SCP to answer the question about the existence of

\footnotetext{
${ }^{23}$ Gentrification serves solely to raise the cost of living, as determined by the real estate market, so that people no longer are able to pay for that space. As a rule, the high cost of living imposes the flight of families to more remote areas or without urban structure, that is, places that they have the condition to pay for to survive.
} 
affirmative actions, public policies or local legislation for the reduction of inequality. The second also has no record of the number of deaths by homicide according to ethnic group in the city. And the third is the Human Development Index, which of the only result is from 2000, with a value of 0.85 .

III. Governance, on track of deliberative participation space and public hearings in the city, "to ensure making responsive, inclusive, participatory and representative decision at all levels." Thus, it was found that there were many meetings and proper disclosure, however, the number of participants was always small when compared to the number of inhabitants in Campinas. This review did not reveal the times that meetings were scheduled, camouflaging a possible manifestation of why it may have had low participation. The second axis means to display the number of blacks in management positions in the municipal government, but there is no record on this point. The third axis indicates accessibility in public spaces.

The mentioned indicators should be used to evaluate the conditions of the city of Campinas, which with the signing of the SCP, has committed to make this city a sustainable city.

Thus, there was the breach of the rules regarding the agreement, since the targets should have been met by December 2017, or at least have been examined as stipulated in a document signed by the City Mayor (SCP, 2017).

On March 31, 2017, the targets set by the Campinas City Hall for the years 2017 to 2020 were published in a special edition of the Official Journal. Among the commitments are included innovation from an efficient, integrated - with reduction of inequalities and distancesand human management, giving priority to citizens and their needs (OFFICIAL JOURNAL, 2017: 5-7).

The plans include efficient, inclusive and human urbanization, from the creation of housing units for the most vulnerable population to the establishment of a new master plan. In addition, it is expected to universalize the collection and treatment of sewage, increasing the capacity to $100 \%$ of the sewage collected in the municipality (OFFICIAL JOURNAL, 2017: 16). Despite what was established, it was not defined by the Municipal Public Administration which group was considered vulnerable, such as blacks, women and children. The way these 
goals were presented without any implementation plan (with prior indication of neighborhoods or even places where minorities are to be met and attended more efficiently) indicates that the goal is not the materialization of mechanisms to solve the existing problems, since these weren't even explicitly exposed.

If there were real intention to promote such inclusion plan, since there are constant information in the IBGE data base that indicates the percentage of blacks and women in each neighborhood of Campinas, as well as income statement and allotments in which the members of these minorities reside. These data were even mentioned in the publication of Campinas City Hall goals.

The National System of Data Analysis, in 2011, pointed out that the city of Campinas has $795.70 \mathrm{~km}^{2}$ with a population of $1,091,946$ inhabitants, and a population density of 1372.31 inhabitants $/ \mathrm{km}^{2}$ (Campinas 2018; IBGE, 2018). This town has, in theory, its decentralization in the following districts: Barão Geraldo, Sousas, Joaquim Egidio, Campo Grande and Ouro Verde, illustrating the existence of economic and racial barriers between the inhabitants of each district. Barão Geraldo and Joaquim Egidio, though distant from the center, are very organized, with exemplary urban planning and access to public facilities and services. Contrary to what occurs in Campo Grande and Ouro Verde.

We confirm that based on 2010 census data from IBGE (IBGE, 2011), illustrating that the neighborhood Cidade Universitária, located in the District of Barão Geraldo, had the total of 9,961 people, 8,858 whites and 654 blacks, in different numbers, $88,92 \%$ of white and $6.56 \%$ of black people. Joaquim Egidio, in the district of Joaquim Egidio, had 891 people, and 693 of them were white while 111 were black, that is, $77,78 \%$ composed of white people and only $12.46 \%$ were black people.

Campo Grande and Florence, both located in the District of Campo Grande, had a total of 43,007 inhabitants, so they had 21,013 whites and black 21,721 blacks, that is, $48.85 \%$ white and $50.51 \%$ black.

Jardim Fernanda, Campituba and Jardim Itaguaçu, corresponding to the District of Ouro Verde, had 18,595 people, including 6,126 whites and 12,379 blacks, respectively, $33.07 \%$ of white and $66.82 \%$ of black people. The segregation by skin color is repeated in other 
neighborhoods of Campinas, although there is no legal standard prohibiting blacks and whites from occupying the same neighborhoods. Still, the apartheid that was built in this city remains (IBGE, 2011). ${ }^{24}$

The residence of black population in peripheral areas does not follow, as a rule, a choice from that group, and instead from the fact of those being the cheapest places (just for the lack of urbanization). Many places are not cheap, but illegal. The illegality of establishing housing in certain locations (watershed areas, environmental conservation areas, hillside areas) prevents agents from the real estate market of advancing on them, but it does not prevent irregular occupation.

The IBGE census (2011) showed that income determines the place of residence and, as blacks receive lower pay, they are located in regions with lower costs. And if they earn these small amounts, it is not for lack of capacity, since in many cases, the lowest remuneration received is a result of the normalization of racist standards by which blacks possess less ability or should not be equated with whites. Skin color determines the value of the person's salary.

\section{SOUTH AFRICA}

As in Brazil, in South Africa the same situation of division of society into ghettos specific to each ethnic group still happens, so that the racial inequality of apartheid was not really extinct in 1990; instead, only the legal rules that legalized the apartheid were extinguished. This should be considered as an important and fundamental stepping stone to the elimination of social inequality, as were extinguished the laws that allowed the structuring of the conditions of racial violence. However, the racist culture is still reproduced and maintained, sometimes in a veiled way, sometimes explicitly, with the same discriminating structures as the previous system.

${ }^{24}$ The indicated data and other municipalities can be verified by the site of Campinas (2018) or IBGE (2011). 
The apartheid regime was institutionalized in the mid-1960s and kept as an official policy of that country until 1990, after the struggles for freedom headed by Nelson Mandela. ${ }^{25}$ From there, with Mandela's election as president in 1994, South Africa declared itself as democratic and repudiated all forms of discrimination, inequality and prejudice (SOUTH AFRICA, 2018).

Despite this formal recognition, racial inequality is still present in its social fabric, so that the socio-spatial segregation in cities is still defined by the criterion of skin color (SEEKINGS, 2007: 4-6).

Like Brazil, the formation of the South African people happened with the invasion of various ethnic groups at the time of the slavery regime. The slaves were formally released in 1834, but the country had already been invaded by the Dutch (1652) and the British (1795). There was conflict between these two countries because each thought it was at their right to control South Africa and its people.

White Europeans fought wars with the South African tribes, who left defeated and having to work in the diamond mines that were under the control of whites. Blacks became miners, while whites were richer.

In 1910, the South African Union was proclaimed, but there was no union whatsoever. The control of all social sectors continued with the whites (Afrikaners). Despite the dominance, they began to worry about the fact that blacks were increasing in their population numbers and could claim the power. So to have no changes in that reality, the laws created by whites curtailed blacks and Indians. ${ }^{26}$

Blacks were completely deprived of their rights when they were driven out of the political and trade unions. Laws called Pass Laws controlled their movement, ensuring that black people did not leave the farms that pertained to whites. Thanks to the set of laws Land Acts of 1913 and 1936, most blacks who continued living in tribes, were also banned from buying land outside the reserves. The 1943 and 1948 elections put the National Party, made up of white people, in power. The party controlled the country until the 1994 elections (SOUTH AFRICA, 2018).

\footnotetext{
${ }^{25}$ He was a South African black leader who was jailed for 27 years due to the ideal of ending apartheid, and won the election (SOUTH AFRICA, 2018).

${ }^{26}$ This group was used as slave labor to work in the diamond mines controlled by the British.
} 
The same justification used for the black inferiority in Brazil was used to ensure the inferiority of all those non-whites. Because of the ethnic diversity arising from the occupation by Indians, Asians and blacks themselves of the tribes; in the fight for control of the diamonds, the South African nation had as a citizen standard the European white. The others were deprived of citizenship.

\begin{abstract}
With the 1948 elections, Hendrick Verwoerd and D.F. Malan created a new world: the apartheid, or "separation." This national political position brought many new laws. Blacks were forced to sit in separate public banks, use different building entrances and have their own public restrooms. The following year, the Mixed Marriages Act decree forbade marriages between blacks and whites. The cruelest decree of all was the People's Registration Act of 1950, which required records according to the racial classifications. Blacks were forced to carry a pass permanently, preventing them from entering the cities. Furthermore, a large number of black were sent to areas called townships - areas of racial segregation and extreme poverty, that the farther away from the eyes of white, the better. For 30 years, the National Party struggled to maintain the apartheid system; which preached the censorship of the media and the lack of freedom of expression. The violence index was increasing as was the number of protests in the country (SOUTH AFRICA, 2018).
\end{abstract}

The rise of Nelson Mandela to presidential power in 1994, allowed the drafting of a new Constitution, with serious intent to the formation of a democratic country. However, as it will be shown in the next section, we found that the rules were created to promote economic development and had no concerns about racial inclusion. The rejection of discrimination and prejudice was prescribed; however, this was not enough to change the reality that still keeps blacks in subalternity.

Data from the Urban Foundation (1990) shows that blacks were more likely to live in shacks because the population was growing faster, but without funding opportunities and access to land (BEAVON, 1992: 232).

\title{
3.1 South African legal system after the elections of 1994 and conditions of the national black
}

From 1993 to 1996, South Africa had a provisional constitution, having been established after discussions with several South African groups in the Constituent Assembly devices that should run the country. Thus, in 1996 it entered into force the Constitution of the Republic of South Africa (SOUTH AFRICA, 2018). 
The preamble states that South Africa is diverse and belongs to all, since, to recognize past injustices, there was set as a goal the establishment of democratic values, social justice and human and fundamental rights.

Many of the 1996 Constitution devices assert that the new South African order is founded on non-racialism and non-sexism, sealing up any kind of discrimination, not being allowed the defense of hatred that is based on race, ethnicity, gender and religion. No one should be deprived of citizenship.

Likewise, we have also identified the recognition of the ethnic and racial diversity in the country when the Constitution recognized eleven languages as their official languages, namely: Sepedi, Sesotho, Setswana, siSwati, Tshivenda, Xitsonga, Afrikaans, English, isiNdebele, isiXhosa and isiZulu.

Despite the formality, as in Brazil, these rules are not enough to erase the entire history of discrimination and existing racial inequality, either to eliminate or at least mitigate the racist social structure that remains.

The concepts of citizenship were not even defined. That is, there are no parameters to know how to measure the exercise of citizenship by South Africans.

Unlike Brazil whose capital is Brasilia, which concentrates the three powers (executive, judicial and legislative), South Africa has three capitals with a power in each: Executive (Pretoria), Legislative (Cape Town) and Judicial (Bloemfontein).

According to statistics, 2018, South Africa has white population (European community, mainly Dutch and English) at 12\%, colored (mixed race) at 8.5\%, Asian (Chinese, Indian) at $2.5 \%$ and blacks (ethnic groups: Zulu, Sotho, Tswana, Xhosa, Tsonga, Swazi, Sale, Ndebele) at $77 \%$ of the entirety of its inhabitants.

Vila Orania, a city next to the South African capital, Pretoria, is a clear expression of the existing barrier to the achievement of racial equality, because it has only allowed white residents, descendants of the colonizers of South Africa. The local news report that the access is denied even to black police officers (GLOBE, 2017). 
The Brazilian reality is not far from this situation because blacks continue to be seen as potential lawbreakers. So much so that, when inserting themselves into white spaces, ${ }^{27}$ it is common for them to be addressed as invaders. ${ }^{28}$

According to Angela Davis (2018: 32) a number of leadership positions previously occupied only by white people, are now occupied by black people, including women. However, this does not preclude the manifestation of racist practices and behaviors, as they are part of the legal and institutional framework, as the Marikana Massacre in 2012 shows, when police killed 36 protesters and wounded 78 to suppress a strike for wage increase a British mining company.

Another coincidence in the form of racial segregation reproduced in both countries is the investment for the construction of housing estates in poor neighborhoods and closed residential communities exclusively in districts composed of privileged people. On the fictitious grounds of providing housing to the poor, there are housing programs like Minha Casa, Minha Vida (Brazil) and "My House, My Life" (South Africa). ${ }^{29}$ On the other hand, the construction of condominiums for the middle and upper class are being expanded, on the grounds of providing security for this class, which is mostly white.

Below, we present the data on housing, violence and income relating to Cape Town, located in the province of Western Cape.

\subsection{Cape Town: Evidence of racist structures}

The city of Cape Town has a total population of 3,740,025 inhabitants, according to the statistics of the city (STATS SA, 2012). The population is composed of the following groups: 42.4\% color, 38.6\% African black, 15, 7\% white, Indian and Asian (put in the same category) and $1.9 \%$ others.

\footnotetext{
${ }^{27}$ Expression used to understand that cities have areas that are occupied, mostly by white people. And these have the protection of their assets, by private and state security. The abnormality, which is the insertion of a black, facing the standard, so that it is treated as an intruder.

${ }^{28}$ Police violence against blacks is evidenced with the characterization in pamphlets distributed to the population, in which criminals agents are invariably characterized as black people.

${ }^{29}$ The Lula Institute (2017) has partnerships with the African Union to promote housing programs similar to Minha Casa, Minha Vida in their countries. Cape Town has similar programs, which differ by income standards (CAPE TOWN, 2018).
} 
Educational inequality between blacks and whites is perceived with the data that found that among adults older than $20,2.5 \%$ of blacks do not have schooling, while only $0.3 \%$ of whites have no schooling (STATUS, 2011).

Regarding income among people between 15 and 64 years, from the total of blacks, $444,781,19.2 \%$ have no income, and from total of whites, $19,522,8.4 \%$ have no income. On the other hand, the number of people who have income above 25,000 , is only $0.4 \%$ for black people (1.615) and $4.4 \%$ for white people $(10,151)$, showing that the higher the income, the lower the existence of blacks, although they represent a higher percentage (STATUS, 2011).

According to data from Cape Town in 1996 the urban population was made of $43 \%$ black and $90 \%$ white, showing that black people had not yet managed to win a place in the city, even with the end of the apartheid regime (STATS SA 2012). The blacks were a minority, at least since 1904 with only $10 \%$ of them occupying the urban space, while whites represented $52 \%$. It turns out that the increase percentage of whites when it comes to space occupation compared to that of blacks is grand, since blacks increased in $23.25 \%$, whites rose up in $57.77 \%$, in another words, white people more than doubled their occupation of the urban space.

The city as we have seen is not a space that can be enjoyed for free, not even the enjoyment of urban experiences.

To combat this reality of exclusion for the usage of the city, the movement "Reclaim the City" promotes campaigns to combat displacement and evictions of working class people, as well as requiring from the State provisions of affordable housing in land in the center of city (RECLAIM THE CITY, 2018). ${ }^{30}$

The struggle of this movement in Cape Town does not have a racial perspective, only a social one, which might even prevent the end of the separation between blacks and whites in the centers.

Cape Town is divided into the following districts: Cape Flats Planning District, Helderberg Planning District, Mitchells Plain Khayelitsha Planning District, Northern Planning

\footnotetext{
${ }^{30}$ The Movement "Reclaim the City" has a formal constitution, and its preamble states that the members of the movement have the right to live in a just and equal city, as well as having access to land (RECLAIM THE CITY, 2018).
} 
District, South Peninsula Planning District, Table Bay Planning District, Tygerberg Planning District, Blaauwberg Planning District (CAPE TOWN, 2011).

Besides the "Reclaim the City," which seeks an inclusive city, and therefore sustainable, Cape Town has the program 100 Resilient Cities (100RC, 2017) which is authored by a foundation responsible for helping cities around the world become more resistant to physical, social and economic challenges, of the XXI century. ${ }^{31}$ From this program, it took place from the $1^{\text {st }}$ to $3^{\text {rd }}$ of February 2018, the International Urban Conference that promoted debates indicating that one of Cape Town's problems, as other African cities, is the growth of informal urbanization, which runs against the search of inclusive and resilient cities. ${ }^{32}$

To oppose spatial segregation, in addition to infrastructure proposals for the planning of water and environmental disasters, 100RC sets guidelines for the mobilization of teams to devise measures for urban planning.

According to the 100RC data, Cape Town recognized that informal settlements are generally excluded from municipal plans and, as a rule, are located in areas prone to physical hazards such as floods, landslides, traffic accidents, pollution, and lack of access to public and basic infrastructure services.

A household survey done by Cape Town in informal settlements pointed out that the problems faced are crime, drug abuse, alcohol, unemployment, water shortages and disease outbreaks. ${ }^{33}$ Such problems are identified in this group of people who have greater difficulty in accessing public services and equipment provided by the state.

\footnotetext{
${ }^{31} 100 \mathrm{RC}$ was created in 2013 and since then has received requests from 94 countries (330 cities) to join the group to be served by the research. The examination of applications is carried out by a group of expert judges. The Program provides funding, training and assistance to help cities change the way they understand the risks and plan for the future. $100 \mathrm{RC}$ is a program funded by the Rockefeller Foundation and managed as a project sponsored by the Rockefeller Philanthropy.

32 100RC indicates that the informal urbanization hinders the formation of the inclusive and resilient city, because it makes the city expand to a point that it ends up extending the social exclusion of the group occupying the informal settlements.

${ }^{33}$ The identified problems relate to class inequality issues, but ethnic disparities were not indicated as a challenge to overcome (CAPE TOWN, 2017).
} 
After identifying these problems or challenges existing in Cape Town, we found that the Integrated Development Plan (IDP) ${ }^{34}$ should establish planning and guidelines for facing and overcoming of these problems.

The IDP at the dates of 2011-2016 and 2017-2022 recognizes that Cape Town has been mapped in a segregated basis because of apartheid deployment, which stated that the non-white had no permission to live in the center or in the areas nearby. There was the forced removal to more distant neighborhoods from downtown, hindering the manifestation, which was suppressed by the oppressive forces in favor of segregation (CAPE TOWN, 2017)

Since 1994, Cape Town is recognized as democratic, because of the ethnic aspect, so that currently the city has a national and international propaganda of its democratic nature because it aims to search for an inclusive future. ${ }^{35}$

To simulate that the equality, inclusion and resilience goal is being fulfilled, South Africa received the World Cup in 2010; ${ }^{36}$ and there was, in 2013-2014, the claiming of lands to the families who were forced to leave their own lands because of apartheid (CAPE TOWN, 2017).

\section{FINAL CONSIDERATIONS}

From the guidelines of the UN/HABITAT III New Urban Agenda, we find that Brazil and South Africa have socially unsustainable cities because, despite the declarations on Human Settlements and the Millennium Declaration and the Goals of Sustainable Development, they continue to present an immense ethnic division throughout the urban territory, up to the point of blacks being in worse places compared to locals held by whites.

\footnotetext{
${ }^{34}$ The IDP is what we have in Brazil as the Master Plan. In Cape Town the IDP 2017-2022 is now in effect.

${ }^{35}$ The IDP 2017-2022 prescribes that planning is fundamental in a city of opportunity, inclusion, well-managed, secure, and who cares about future generations (CAPE TOWN, 2018).

${ }^{36}$ The South African World Cup showed that non-whites do not attend the same environments of whites. For example, in the stands of football matches, sporadically some non-white or black person was seen watching the game. The absence of blacks in these spaces arises from the absence of conditions for them to be shouldering the costs, and it happens because of a stigma that was built and standardized.
} 
We found that the urban planning of these countries has never been done in order to restrain discriminatory actions, under the terms of the UN Declaration, so that the settings would need to suffer a break to see the end of this reproduction of normality or naturalness about racial discrimination.

That is, while there are egalitarian social development plans, it seems that they remain bound to fail. It seems that, if they are voted, there is no interest in its implementation, there is no interest in fighting the normalization of racial segregation reproduced in the form of cultural violence, resulting in the absence of policies to promote the deghettoization of the black population.

The maintenance of ethnic tensions between whites and blacks, both in Brazil and in South Africa, serves to perpetuate the privileges of the white group, so that racism is not defined as a social problem. Thus, social inclusion, though it may be formally discussed and treated in public policies of urban development, so far, did not take into account the racial equality factor, which perpetuates the racial segregation in urban areas.

The formation of each city happened differently and at different times, however, the democratization took place in periods close to one another. There was a change in the rules, which formally combats racism. On the other hand, the data collected shows that both cities have yet to develop and implement deghettoization policies.

\section{REFERENCES}

SOUTH AFRICA. Embassy of the Republic of South Africa, 2018. Available at:http://www.africadosul.org.br/. Accessed on: april 4, 2020.

AGUIAR, Joaquim Castro. Direito da Cidade. Rio de Janeiro: Renovar 1996.

Beavon, K.S.O. The post-apartheid city: hopes, possibilities, and harsh realities. In: SMITH, David M. THE APARTHEID CITY AND BEYOND Urbanization and Social Change in South Africa. London and New York: Routledge; Witwatersrand University Press, 1992, p. 232-243.

CAPE TOWN. Available at: 〈http://www.capetown.ggov.za〉. Accessed on: april 4, 2020.. 
CAPE TOWN. Cape Town censuses and population statistics, 2011. Available at:http://www.capetown.gov.za/Family\%20and\%20home/education-and-researchmaterials/data-statistics-and-research/cape-town-census. Accessed on: April 5, 2020.

CAPE TOWN. Housing opportunities, 2018.http://www.capetown.gov.za/Family\%20and\%20home/residential-property-andhouses/city-housing-opportunities/housing-opportunities>. Accessed on: April 5, 2020.

DAVIS, Angela. A liberdade é uma luta constante. Translation by Heci Regina Candiani. 1.ed. São Paulo: Boitempo, 2018.

DAVIS, Angela. Mulheres, Cultura e Politica. Translation by Heci Regina Candiani. 1.ed. São Paulo: Boitempo, 2017.

FERNANDES, Florestan. A integração do negro na sociedade de classes: o legado da raça branca. 5. ed. Sao Paulo: Globo, v.1, 2008.

GUIMARÃES, Antônio Sérgio Alfredo. Entrevista com Hasenbalg. Tempo Social USP's sociology magazine, v. 18, n. 2, 2006, p. 259-268. Available at: http://www.scielo.br/pdf/ts/v18n2/a13v18n2. Accessed on: April 6, 2020.

GUIMARAES, Antonio Sérgio Alfredo. Combatendo o racismo: Brasil, África do Sul e Estados Unidos Geledés Black Women's Institute, 2014. Available at: <http://www.geledes.org.br/combatendo-o-racismo-brasil-africa-sul-e-estadosunidos/\#gs.null>. Accessed on: April 6, 2020.

IANNI, Octavio. Raças e classes sociais no Brasil. 2. ed.rev.mod. Rio de Janeiro: Civilização Brasileira, 1972.

IBGE. Brazilian Institute of Geography and Statistics. National survey by continuous household sample, 2011. Available at: https://www.ibge.gov.br/estatisticasnovoportal/sociais/populacao/9171-pesquisa-nacional-por-amostra-de-domicilios-continuamensal.html?=\&t=o-que-e. Accessed on: April 6, 2020.

IBGE. Overview of the city of Campinas, 2018. Available at: https://cidades.ibge.gov.br/brasil/sp/campinas/panorama. Accessed on: April 6, 2020.

LULA INSTITUTE. A meeting between Brazil and Africa, 2017. Available at: <http://www.institutolula.org/africa>. Accessed on: April 6, 2020.

Izsák, Rita. UN report on minorities, Feb/2016. Available at $<$ http://ap.ohchr.org/documents/dpage_e.aspx?si=A/HRC/31/56/Add.1>. Accessed on: April 6, 2020.

LEFEBVRE, Henri. $O$ Direito à Cidade. Translation by Rubens Eduardo Frias. São Paulo: Centauro, 2001.

MARICATO, Ermínia. As idéias fora do lugar e o lugar fora das idéias. In: ARANTES, Otília; VAINER, Carlos, e MARICATO, Ermínia. Desmanchando consensos. Petrópolis: Vozes, 
2000, p. 121-192. Available at: < http://labcs.ufsc.br/files/2011/12/07.-MARICATO-E.-Asid\%C3\%A9ias-fora-do-lugar-e-o-lugar-fora-das-id\%C3\%A9ias.pdf $>$. Accessed on: April 4, 2020.

MEIRELLES, Hely Lopes. Direito Municipal Brasileiro. 16.ed. São Paulo: Malheiros, 2008.

MBEMBE, Achille. A crítica da Razão Negra. Tradução de Marta Lança. Antígona, 3. ed, 2014.

NEW URBAN AGENDA. HABITAT 3, 2016. Available at: http://habitat3.org/the-new-urbanagenda. Accessed on: April 5, 2020.

THE GLOBE. South African community keeps the remnants of apartheid alive, 2017. Available at: $\quad$ https://oglobo.globo.com/mundo/comunidade-sul-africana-mantem-vivos-restos-doapartheid-8559115. Accessed on: April 7, 2020.

MUNICIPALITY of Campinas. Historical formation of Campinas, 2006. Available at: <http://www.campinas.sp.gov.br/governo/seplama/publicacoes/planodiretor2006/pdfinal/cap1 .pdf>. Accessed on: April 6, 2020.

MUNICIPALITY of Campinas. Municipal Administration. Auditing Department. Campinas Symbols Primer. Campinas: 2008. Available at: http://campinas.sp.gov.br/sa/impressos/adm/FO757.pdf. Accessed: May 28, 2008, p. 9-40. Accessed on: April 6, 2020.

RECLAIM THE CITY. Reclaim the city: land for people, not for profit. 2018. Available at: <http://reclaimthecity.org.za/why-reclaim-the-city/>. Accessed on: April 6, 2020.

REIS, Émilien Vilas Boas; VENÂNCIO, Stephanie Rodrigues. O direito à cidade e a participação popular no planejamento urbano municipal. Revista de Direito e Desenvolvimento, João Pessoa, v. 7, n. 2, 2016, p. 222-247. Available at: https://periodicos.unipe.br/index.php/direitoedesenvolvimento/article/view/326. Accessed on: April 8, 2020.

RODRIGUES, Gustavo Távora. O racismo escondido sob o manto da lei. Revista Direito e Práxis. v.3, n.5, 2012, p. 70-91. Available at: <http://www.epublicacoes.uerj.br/index.php/revistaceaju/issue/view/363>. Accessed on: April 10, 2020.

ROLNIK, Raquel. Territórios negros nas cidades brasileiras. 1989. Available at: <https://raquelrolnik.files.wordpress.com/2013/04/territc3b3rios-negros.pdf>. Accessed on: April 10, 2020.

SANTOS, Milton. A urbanização brasileira. Coleção estudos urbanos. São Paulo: Editora Hucitec, 1993.

SANTOS, Milton. O país distorcido: O Brasil, a globalização e a cidadania. . Organization and presentation of Wagner Costa Ribeiro, essay by Carlos Walter Porto Gonçalvez. São Paulo: Publifolha, 2002. 
SCHWARCZ, Lilia Moritz. O Espetáculo das Raças: cientistas, instituições e questão racial no Brasil 1870-1930. São Paulo: Companhia das Letras, 1993.

SEEKING, Jerimy. Race discrimination and diversity in South Africa. Center for Social Science Research, n. 194, May, 2007. Available at: <http://cssr.uct.ac.za/publications/workingpaper/2007/race-discrimination-and-diversity-south-africa>. Accessed on: April 10, 2020.

SILVA, Graziella Moraes. A interface entre raça e identidade nacional no Brasil e na África do Sul. Revista de Estudos Políticos, v.1, n.6, 2013, p.44-60. Available at: <http://revistaestudospoliticos.com/wp-content/uploads/2013/10/6p44-60.pdf>. Accessed on: April 10, 2020.

STATS SA. Statistics from South Africa, 2012. Available at: http://www.statssa.gov.za/?page_id=1021\&id=city-of-cape-town-municipality. Accessed on: April 10, 2020.

STATUS. Statistics from Cape Town, 2011. Available at:http://www.capetown.gov.za/Family\%20and\%20home/education-and-researchmaterials/data-statistics-and-research/cape-town-census\#Heading1. Accessed on: April 5, 2020.

SKIDMORE, Thomas E. Preto no Branco: Raça e nacionalidade no pensamento brasileiro. Tradução Donaldson M. Garschagen. 1 ${ }^{a}$.ed. São Paulo: Companhia das Letras, 2012

VEDOVATO, Luis Renato; BARRETO, Michelle Camille. Tratados Internacionais de Direitos Humanos e o Estado Brasileiro: incentivo na construção de políticas públicas. Revista de Pesquisa em Políticas Públicas. 6 ${ }^{\text {. }}$. Ed., 2015, p. 32-48. Available at: $<$ http://www.egov.ufsc.br/portal/sites/default/files/tratados_internacionais_de_direitos_human os_e_o_estado_brasileiro_incentivo_na_construcao_de_politicas_publicas.pdf $>$. Accessed on: April 10, 2020.

WACQUANT, Loïc. Que é gueto? Construindo um conceito sociológico. Tradução de Zena Eisenberg e João Feres Júnior. Rev. Sociol. Polít., Curitiba, 23, nov. 2004, p. 155-164.

WACQUANT, Loïc. As duas faces do gueto. Tradução de Paulo Cezar Castanheira. 1.ed. São Paulo: Boitempo Editorial, 2008.

Data de Submissão: 19/04/2020

Data de Aceite: 02/05/2020 